\title{
The Influence of Abattoir Wastes on Macroinvertebrate Distribution in River Idemili, Obosi, South-Eastern Nigeria
}

\author{
Keziah N. IBEMENUGA ${ }^{1}$, Blessing C. NDUBA ${ }^{1}$, Joseph E. EYO ${ }^{2 *}$ \\ ${ }^{1}$ Anambra State University, Department of Biological Sciences, Uli, Anambra State, \\ Nigeria; ibemenugakn@gmail.com; blessingnduba@yahoo.com \\ ${ }^{2}$ University of Nigeria, Faculty of Biological Sciences, Department of Zoology and Environmental Biology, Nsukka, Enugu State, \\ Nigeria; joseph.eyo@unn.edu.ng ("correspondingauthor)
}

\begin{abstract}
The influence of abattoir wastes on macroinvertebrates distribution in River Idemili, South-Eastern Nigeria, was studied. Three sampling stations 1, 2 and 3 representing upstream of the impacted site, impacted site and downstream of the impacted site respectively were selected. The water quality characteristics, which were significantly different $(p<0.05)$ among the study stations, include water temperature, conductivity, dissolved oxygen and biochemical oxygen demand and phosphatephosphorus. There was no significant difference $(\mathrm{p}>0.05)$ in the levels of $\mathrm{pH}$ and nitrate-nitrogen among the study stations. Thirteen taxa composed of 201 individuals were encountered. Station 1 had the highest taxa (13) species, as well as the number of individuals $(92,45.8 \%)$, followed by station 3 with 12 species and 64 (31.8\%) individuals. Station 2 had the least diversity and abundance of 6 species composed of $45(22.4 \%)$ individuals. Macroinvertebrate abundance in the study stations were significantly different $(\mathrm{p}<0.05)$. Arthropoda $(54.7 \%)$ was the dominant phylum. Chironomids (Family: Chironomidae) dominated the samples at all the study stations. Coleoptera was completely absent at the impacted site due to organic pollution. Margalefs species richness and Shannon Wiener index for general diversity were the highest in stations 1 and 3 . The low macroinvertebrate abundance, species richness and Shannon diversity index in station 2 may be attributed to the decimating impacts of abattoir wastes entering the water in this station. Renkonen's number calculated for pairs of stations revealed that stations 1 and 3 were significantly similar, while stations 1 and 2, 2 and 3 were dissimilar. Conclusively, abattoir wastes distort water quality and affect the community structure, composition, distribution and abundance of macroinvertebrates inhabiting aquatic ecosystems.
\end{abstract}

Keywords: abattoir wastes, macroinvertebrates, Idemili River, water quality

\section{Introduction}

Macroinvertebrates are animals without backbone and are larger than $1 \mathrm{~mm}$ in length. They tend to respond to environmental changes more rapidly than do larger aquatic animals such as fish (Ofojekwu et al., 1996). Thus they have proved to be excellent indicators of apparent and subtle alterations in the quality of freshwater systems (Gibbons and Funk, 1982). Rosenberg (1998) listed compelling reasons for the apparent popularity of freshwater macroinvertebrates in current biomonitoring practice to include the following: i) they are ubiquitous, so they are affected by perturbations in many different habitats; ii) they are species rich, so the large number of species produces a range of responses; iii) they are sedentary, so they stay put, which allows determination of the spatial extent of a perturbation; iv) they are long-lived, which allows temporal changes in abundance and age structure to be followed; and v) they integrate conditions temporally, so like any biotic group, they provide evidence of conditions over long periods of time.

The dynamics of stream macro-invertebrates is influenced, by a number of factors such as geomorphology, physicochemical and biological factors as well as the pollution status of the water (Anadu, 1987; Galicka et al., 1992; Ofojekwu et al., 1996).

River Idemili, Obosi section, receives effluent from the abattoir in Umuota Akuora, Obosi town. The effluents pollute water channel to the extent that it becomes deleterious to aquatic animals. There is no documented information on the pollution status of these effluents. The present study is therefore conducted to determine the status of abattoir effluents on water channel and to assess the influence of these effluents on the abundance and distribution of macroinvertebrates. 
481

Results of this study may contribute significantly to our current knowledge on the present condition of River Idemili. This study presents the first baseline data for macroinvertebrates in this River.

\section{Materials and Methods}

\section{Studyarea}

The study was carried out in the River Idemili, Obosi section, located between latitudes $6^{\circ} 04^{\prime}$ and $6^{\circ} 09^{\prime} \mathrm{N}$ and longitudes $7^{\circ} 48^{\prime}$ and $7^{\circ} 54^{\prime} \mathrm{E}$. Its coordinates were $6^{\circ}$ $11.667^{\prime} \mathrm{N}$ and $6^{\circ} 7.667^{\prime} \mathrm{E}$ (in decimal degrees) (Fig. 1). It lies approximately $7 \mathrm{~km}$ south of Onitsha, along the old Owerri-Onitsha Trunk road. The River is principally fed by Mmiri Nkisi Stream, Oba, in addition to surface run off and discharged effluents from residential buildings and adjoining abattoir along its bank. It flows from north-east to south-west direction emptying into the River Niger. The abattoir is in Umuota Akuora, Idemili junction, Obosi.

\section{Sampling stations}

Three sampling stations were studied. The stations were selected based on accessibility and human activities.

Station 1: This station is partly sandy and partly loamy. Farming is the main human activity occurring around this station. Macrophytes growing along its banks include Colocasia esculenta and Elaeis guineensis.

Station 2: Station 2 has the abattoir located near to it.
The soil is sandy, loamy and clayey. Some parts of the soil are oily as a result of fat and oil from the abattoir. Flames from burnt tires and woods used in roasting skin, head and legs of slaughtered animals foul the air around this station. The waste in this station has foul odor. Aquatic plants in and around the banks of this station include Heteropogon contortus, Raphia hookeri and Bambusa vulgaris.

Station 3: This station lies near the bridge along OwerriOnitsha express road, with a bridge known as Idemili Bridge across the River. The soil in this station is sandy soil. Human activities here include offering of sacrifices to idols, washing of motor cycles and clothes, bathing, swimming and disposal of refuse. Psidium sp. and Heteropogon contortus were among the macrophytes growing along the banks of this station.

\section{Sample collection and analysis}

Water samples were collected biweekly from the study stations for a period of six months (February - July, 2014) using plastic containers, dissolved oxygen bottles and biochemical oxygen demand bottles labelled according to stations.

Both water temperature and $\mathrm{pH}$ were determined in the field using mercury-in-glass thermometer and a portable $\mathrm{pH}$ meter. Conductivity was determined by using a $\mathrm{HACH}$ conductivity/TDS meter. Water samples for dissolved oxygen (DO) were fixed in the field with $1 \mathrm{ml}$ manganous sulphate solution and $1 \mathrm{ml}$ potassium iodide solution.

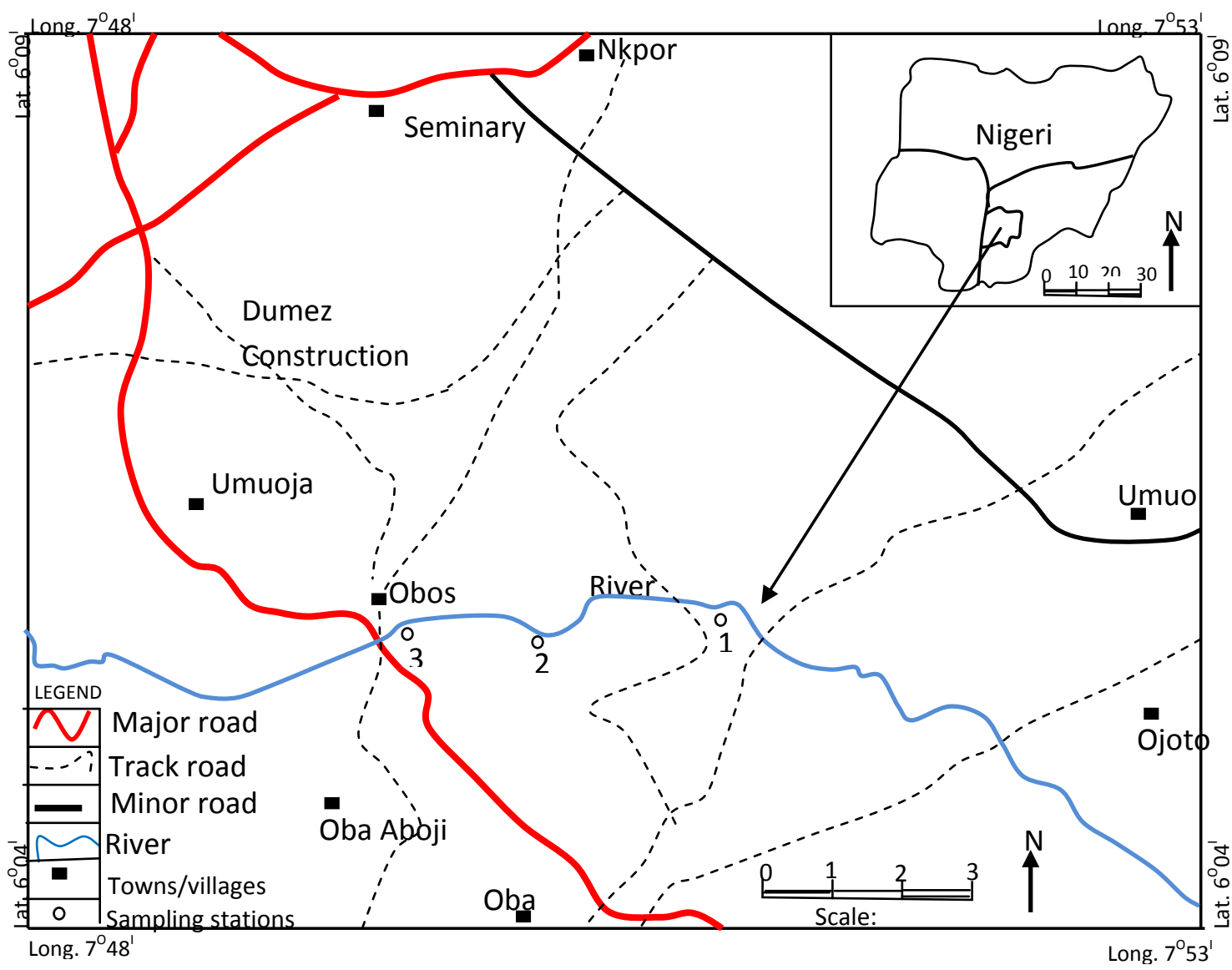

Fig.1. River Idemili, Obosi section showing sampling stations (inset: map of Nigeria showing the study area 
482

Dissolved oxygen was determined titrimetrically using Winklers method described by APHA (1998). Biochemical oxygen demand (BOD) was also determined using titrimetric method following the methods of APHA (1998). Phosphate-phosphorus and nitrate-nitrogen were determined using spectrophotometric method according to APHA (1998).

Macroinvertebrates were collected by the kick sampling method (Victor and Ogbeibu, 1985). The collected animals were preserved in $10 \%$ formalin in containers labelled according to stations. The fauna were transported to laboratory where they were observed under a binocular microscope and identified using relevant taxonomic keys (Pennak, 1978; Egborge, 1993; Thorp and Rogers, 2011).

\section{Statistical analysis}

The statistical methods used in analyzing water quality parameters and macroinvertebrate communities were adopted from Magurran (1988). Biodiversity was evaluated using Margalefs index for species (taxa) richness, Shannon Wiener index $(\mathrm{H})$ for general diversity and the evenness index (E) which is the ratio of $\mathrm{H}$ and $\mathrm{H}_{\max }$, the maximum expected diversity of the community (Odum, 1971; Krebs 1978; Zar, 1984; Ogbeibu and Egborge, 1995).

\section{Results and Discussion}

\section{Physicochemical parameters}

A summary of the physical and chemical parameters of the river at the study stations is presented in Table 1 . The mean, minimum and maximum values of the parameters are shown. Water temperature was maximum in station 2 (28.9 $\pm 1.02{ }^{\circ} \mathrm{C}$ ) with a range of $27.8-31.2^{\circ} \mathrm{C}$. The least mean value of $25.3 \pm 0.93^{\circ} \mathrm{C}$ (range $26.0-28.5^{\circ} \mathrm{C}$ ) occurred in station 1 . The mean temperature values were significantly different $(p<0.05)$ at the study stations. The mean temperature value recorded in station 2 was significantly different $(p<0.05)$ from the values of all other stations. The mean temperature values recorded during the study were within the WHO limit of $29{ }^{\circ} \mathrm{C}$ (maximum allowable) (WHO, 2004). Fair temperature is conducive for microbial activities that degrade organic matters and thus contributes to the purification of the stream (Agwa et al., 2013).

The mean conductivity values recorded in the study stations were significantly different $(\mathrm{p}<0.05)$. Conductivity which was lowest in station 1, peaked in station 2 (24.7 \pm $5.14 \mu \mathrm{Scm}^{-1}$, range $\left.18.3-30.4 \mu \mathrm{Scm}^{-1}\right)$ and decreased in station 3. The maximum value in station 2 may be attributed to abattoir effluents disposed into it. The levels of mean conductivity values obtained in the three stations were lower than WHO allowable limit of $40 \mu \mathrm{Scm}^{-1}$ (WHO, 1993). The low variability in conductivity obtained contradicts the high variability obtained in Kigera reservoir (Aboheweyere, 1990) and connotes regular mineralization of nutrients and allochthonous loadings (King, 1998).

Mean $\mathrm{pH}$ values of $6.3 \pm 0.78,6.2 \pm 0.52$ and $6.0 \pm 0.89$ reported in stations 1,2 and 3 respectively were below the WHO limits of $6.5-8.5$. $\mathrm{pH}$ was slightly acidic in all the study stations. $\mathrm{pH}$ values were not significantly different $(p>0.05)$ in the study stations. Dissolved oxygen necessary for respiration also varied in the three stations from $2.7 \pm$ $1.00 \mathrm{mg} / \mathrm{l}$ (range $1.2-4.0 \mathrm{mg} / \mathrm{l})$ in station 2 to $4.8 \pm 0.27$ $\mathrm{mg} / \mathrm{l}$ (range, $1.25-2.60 \mathrm{mg} / \mathrm{l}$ ) in station 1 . The values were significantly different $(p<0.05)$. Comparatively the values were below the WHO minimum allowable limit of $6 \mathrm{mg} / \mathrm{l}$ (WHO, 1993).

The least dissolved oxygen mean value in station 2 may be attributed to the breakdown of abattoir effluents by micro-organisms. The organic materials such as abattoir wastes could form sludge which according to Waldichuk (1974) and Arimoro et al. (2006) decomposes through activities of micro-organisms, depleting oxygen from the bottom waters and forming noxious gases. Dissolved oxygen concentrations in unpolluted water normally range between 8 and $10 \mathrm{mg} / \mathrm{l}$ (Jordan et al., 1990; DFID, 1999; Agwa et al., 2013). The levels of dissolved oxygen recorded at the three study stations were below $5 \mathrm{mg} / \mathrm{l}$ which Dondurff and Shunway (1998) described as the minimum concentration of dissolved oxygen in freshwater necessary to accommodate aquatic life. Thus the discharge of abattoir wastes into the river had deleterious effects on dissolved oxygen concentrations of Idemili River section of Obosi. Adeniji (1986) reported dissolved oxygen as one of the most important factors which an aquatic organism cannot survive without. Smart (2002) reported that water body will simply become uninhabitable to most desirable aquatic life without adequate dissolved oxygen and that at normal temperature, water is said to be saturated with oxygen at $9 \mathrm{mg} / \mathrm{l}$, a saturation value that decrease rapidly with increasing water temperature. The dissolved oxygen values of $4-5 \mathrm{mg} / \mathrm{l}$ are essential for aquatic life (Tubonimi et al., 2010).

The maximum mean value of biochemical oxygen demand $(5.40 \pm 1.12 \mathrm{mg} / \mathrm{l})$ recorded in station 2 was significantly different $(p<0.05)$ from the values of all other stations. This was followed by station 3 with mean value of $8.23 \pm 1.71 \mathrm{mg} / \mathrm{l}$ (range $1.0-4.90 \mathrm{mg} / \mathrm{l})$. Station 1 had the least mean value $(1.69 \pm 0.50 \mathrm{mg} / \mathrm{l}$, range $1.25-2.60 \mathrm{mg} / \mathrm{l})$. There was significant difference between these values $(p<0.05)$. These values which were higher than the values obtained in Barnawa stream (Emere and Nasiru, 2008) and were below the WHO standard of $50 \mathrm{mg} / \mathrm{l}$ (WHO, 1993; 2004). The high level of biochemical oxygen demand obtained in station 2 could be as a result of metabolic activities of micro-organisms on abattoir wastes. Aerobic bacteria and other micro-organisms use organic matter present in water as nutrient (Ganf and Viner, 1973). Increase in biochemical oxygen demand triggers eutrophication (Smith et al., 1999).

The mean phosphate-phosphorus recorded during the study was highest in station $2(2.52 \pm 0.47 \mathrm{mg} / \mathrm{l})$ and lowest in station $1(0.23 \pm 0.05 \mathrm{mg} / \mathrm{l})$ with a range of $2.12-2.88$ $\mathrm{mg} / \mathrm{l}$ and $0.03-0.12 \mathrm{mg} / \mathrm{l}$ respectively. The level of phosphate-phosphorus in station 2 was significantly different $(\mathrm{p}<0.05)$ from the means of stations 1 and 3 . Phosphate is one of the principal nutrients that limit the productivity of tropical waters (Ekeh and Sikoki, 2003). The mean level of phosphate-phosphorus of Idemili River, Obosi section fell below the EPA (2009) limit of $10 \mathrm{mg} / \mathrm{l}$.

Nitrate-nitrogen varied slightly at the study stations. Station 2 which is the discharge point had the maximum mean value $(0.62 \pm 0.45 \mathrm{mg} / \mathrm{l})$ while station 1 had the minimum mean value $(0.32 \pm 0.33 \mathrm{mg} / \mathrm{l})$. There was no significant difference $(p>0.05)$ between the values recorded in the stations. Low levels of nitrate indicated good health status and self-purification capacity of the river (Agwa et al., 2013) despite discharge of abattoir effluents into it. 
Table 1. Summary of physicochemical properties of River Idemili

\begin{tabular}{|c|c|c|c|c|c|c|c|c|c|c|c|c|}
\hline \multirow[b]{2}{*}{ Parameter } & \multirow{2}{*}{$\begin{array}{l}\text { Standard } \\
\text { used }^{\bullet}\end{array}$} & \multicolumn{3}{|c|}{ Station 1} & \multicolumn{3}{|c|}{ Station 2} & \multicolumn{3}{|c|}{ Station 3} & \multirow{2}{*}{$\begin{array}{l}\text { F-value } \\
\text { ANOVA }\end{array}$} & \multirow[b]{2}{*}{ Sig. } \\
\hline & & $\begin{array}{c}\text { Mean } \pm \\
\text { S.E. }\end{array}$ & Min & Max & $\begin{array}{c}\text { Mean } \pm \\
\text { S.E. }\end{array}$ & Min & Max & $\begin{array}{c}\text { Mean } \pm \\
\text { S.E. }\end{array}$ & Min & Max & & \\
\hline Water temperature & 29 & $25.3 \pm 0.93$ & 26.0 & 28.5 & $28.9 \pm 10.2$ & 27.8 & 31.2 & $27.5 \pm 1.18$ & 26.0 & 29.5 & $12.36^{*}$ & $\mathrm{p}<0.05$ \\
\hline Conductivity & 40 & $3.1 \pm 0.73$ & 2.3 & 4.2 & $24.7 \pm 5.14$ & 18.3 & 30.4 & $15.3 \pm 2.05$ & 3.0 & 8.3 & $50.92^{*}$ & $\mathrm{p}<0.05$ \\
\hline $\mathrm{pH}$ & $6.5-8.5$ & $6.3 \pm 0.78$ & 5.6 & 7.5 & $6.2 \pm 0.52$ & 5.8 & 7.2 & $6.0 \pm 0.89$ & 5.0 & 6.9 & 0.58 & $\mathrm{p}>0.05$ \\
\hline $\begin{array}{c}\text { Dissolved oxygen } \\
(\mathrm{mg} / \mathrm{l})\end{array}$ & 6 & $4.8 \pm 0.27$ & 2.6 & 3.3 & $2.7 \pm 1.00$ & 1.2 & 4.0 & $4.4 \pm 0.79$ & 3.4 & 4.5 & $5.23^{*}$ & $\mathrm{p}<0.05$ \\
\hline $\begin{array}{c}\text { Biochemical Oxygen } \\
\text { demand }(\mathrm{mg} / \mathrm{l})\end{array}$ & 50 & $1.69 \pm 0.50$ & 1.25 & 2.60 & $5.40 \pm 1.12$ & 3.80 & 6.80 & $3.83 \pm 1.71$ & 1.0 & 4.90 & $6.47^{*}$ & $\mathrm{P}<0.05$ \\
\hline $\begin{array}{l}\text { Phosphate phosphorus } \\
\qquad(\mathrm{mg} / \mathrm{l})\end{array}$ & 10 & $0.23 \pm 0.05$ & 0.03 & 0.12 & $2.52 \pm 0.47$ & 2.12 & 2.88 & $1.53 \pm 0.05$ & 0.03 & 0.04 & $5.76^{*}$ & $\mathrm{P}<0.05$ \\
\hline Nitrate-nitrogen & 10 & $0.32 \pm 0.33$ & 0.02 & 0.9 & $0.62 \pm 0.45$ & 0.2 & 1.2 & $0.42 \pm 0.25$ & 0.3 & 0.10 & 1.60 & $\mathrm{P}>0.05$ \\
\hline
\end{tabular}

\section{Macroinvertebrate composition, abundance and distribution}

The overall macroinvertebrate composition, abundance and distribution in the study stations are shown in Table 2. Thirteen taxa composed of 201 individuals were encountered in the study. Station 1 had the highest taxa $(13$ species) and number of individuals $(92,45.8 \%)$, closely followed by station 3 (12 species) with 64 (31.8\%) individuals. Station 2 had the least species diversity and abundance of 6 species composed of $45(22.4 \%)$ individuals.

Macroinvertebrate abundance in the study stations were significantly different $(\mathrm{p}<0.05)$. Station 1 was significantly different $(p<0.05)$ from stations 2 and 3. The dipteran Chironomids (Family: Chironomidae) dominated the samples at all stations. The chironomids are the most abundant and diverse group of insects inhabiting freshwater environments. Chironomidae larvae are quite important in production of benthic biomass. They are found in different aquatic benthos because of their ability to adapt to extremes of some physicochemical parameters of the benthic environment (Bhosale et al., 2012). Members of the family Chironomidae constitute the most abundant group of benthic freshwater macroinvertebrates in terms of both species and abundance (Armitage et al., 1995). The dominant species was Chironomus sp. The dominance of Chironomus among the sampled stations of a freshwater ecosystem, Sombreiro River, Niger Delta, Nigeria has been reported to be normal (Ezekiel et al., 2011) and Chironomids dominance of macroinvertebrate fauna of freshwater muds has been earlier reported (Statzner and Higler, 1986). The low macroinvertebrate abundance at the impacted site may be attributed to stressors in the ecosystem and destruction of the microhabitat (Ezekiel et al., 2011). Macroinvertebrates were lowest or even absent in impacted areas i.e. sources of pollutant discharges.

The Coleoptera was completely absent at the impacted site perhaps due to organic pollution. Trevor et al. (2010) had listed pollution sensitive taxa to include Coleoptera. The main groups of macroinvertebrates recorded during the study and their percentage contribution in the stations are presented (Table 3, Fig. 2). Arthropoda which formed $54.7 \%$ of all individuals dominated the samples in the three stations. It had the highest number of taxa (7) with percentage contribution of 52.2, 64.4 and 51.6 in stations 1 , 2 and 3 respectively. Such dominance of arthropods in polluted streams has earlier been reported in Ayiroor River, Kerala, South India (Ambili and Reenamole, 2016).

The phylum mollusca accounted for $32.3 \%$ of all individuals. It was most important in station $1(44.6 \%)$ and least in station 2 (6.7\%). The association of molluscans with polluted freshwater ecosystems has been reported in the Mediterranean basins (Perez-Quintero, 2011).

According to Johnson (2005), the rapid decline in diversity and abundance of freshwater snails was attributed to a variety of human activity that leads to degradations of their natural habitats. The most important impacts include: (i) channelization and dredging, (ii) dams and impoundments, (iii) sedimentation and channel instability and (iv) water pollution.

Annelida with one species (Eiseniella sp. Oligochaetae) and overall percentage of 12.9 accounted for 3.3, 28.9 and $15.6 \%$ in stations 1,2 and 3 respectively (Fig. 3 ). The low dominance of the oligochaetes in polluted waters has been reported by Ayoade and Olusegun (2012) for macrobenthic invertebrates of River Ogbere, Southwestern Nigeria, where they recorded $1.95 \%$ of Eiseniella sp. In their study, the reported that the Oligochaetae correlated negatively with water depth, turbidity, nitrate, phosphate, TSS, iron, manganese and positively with DO.

Table 4 showed diversity indices computed for Margalefs species richness, Shannon-Wiener diversity $(\mathrm{H})$, evenness and dominance at the study stations. Species richness and Shannon-Wiener index for general diversity were each highest in station 1 followed by station 3 and lowest in station 2. Evenness was highest in station 3 and lowest in station 2. Dominance index ranged from 0.096 in station 1 to 0.327 in station 2 . The low macroinvertebrate abundance, species richness and Shannon diversity index in station 2 may be attributed to the decimating impacts of abattoir wastes entering the water in this station.

The Renkonen's number calculated for pairs of stations of River Idemili is shown in Table 5. Stations 1 and 3 were significantly similar while stations 1 and 2, 2 and 3, were dissimilar. Renkonen's number is based on a comparison of the total faunal content of two or more sites and it uses the criteria of relative abundance (Ogbeibu, 2005). 
484

Table 2. Composition, abundance and distribution of macroinvertebrates in the study stations of River Idemili

\begin{tabular}{|c|c|c|c|}
\hline \multirow{2}{*}{ Taxa } & \multicolumn{3}{|c|}{ Stations } \\
\hline & 1 & 2 & 3 \\
\hline $\begin{array}{c}\text { Annelida (Plesiopora). } \\
\text { Eiseniella sp. }\end{array}$ & 3 & 13 & 10 \\
\hline $\begin{array}{l}\text { Arthropoda (Odonata). } \\
\text { Lixus augustatus }\end{array}$ & 3 & 1 & 5 \\
\hline Anax sp. & 15 & - & - \\
\hline Libellula sp. & 4 & 7 & 4 \\
\hline Ischnura sp. & 5 & - & 7 \\
\hline \multicolumn{4}{|l|}{ Diptera } \\
\hline Chironomous sp. & 18 & 21 & 11 \\
\hline \multicolumn{4}{|l|}{ Coleoptera } \\
\hline Haliplus sp. & 1 & - & 1 \\
\hline Dytiscus marginalis & 2 & - & 5 \\
\hline Mollusca (Gastropoda). & & & 5 \\
\hline Bulinus sp. & 7 & 2 & 3 \\
\hline Lymnaea sp. & 10 & - & 6 \\
\hline Lymnaea auricularia & 9 & 1 & 6 \\
\hline Lymnaea collumella & 6 & - & 6 \\
\hline Marisa sp. & 9 & - & - \\
\hline Total & 92 & 45 & 64 \\
\hline Percentage & $45.8 \%$ & $22.4 \%$ & $31.8 \%$ \\
\hline
\end{tabular}

Table 3. Percentage contribution of major macroinvertebrate groups in the study stations

\begin{tabular}{ccccc}
\hline \multirow{2}{*}{ Taxa } & \multicolumn{3}{c}{ Overall total } \\
\cline { 2 - 5 } & 1 & 2 & 3 & 12.9 \\
\hline Annelida & 3.3 & 28.9 & 15.6 & 54.7 \\
Arthropoda & 52.2 & 64.4 & 51.6 & 32.3 \\
Mollusca & 44.6 & 6.7 & 32.8 & \\
\hline
\end{tabular}

Table 4. Diversity, richness, evenness and dominance indices of macroinvertebrates at the study stations of River Idemili

\begin{tabular}{cccc}
\hline Ecological indices & Station 1 & Station 2 & Station 3 \\
\hline No. of taxa & 13 & 6 & 11 \\
No. of individuals & 92 & 45 & 64 \\
Species richness index (d). & 2.654 & 1.313 & 2.404 \\
Shannon - Wiener index (H). & 2.331 & 1.301 & 2.283 \\
Evenness index (E). & 0.909 & 0.726 & 0.952 \\
Dominance (C). & 0.096 & 0.327 & 0.111 \\
\hline
\end{tabular}

Table 5. Coincidence table showing Renkonen numbers calculated for pairs of sampling stations of River Idemili

\begin{tabular}{cccc}
\hline & Station 1 & Station 2 & Station 3 \\
\hline Station 1 & 1.00 & 36.06 & $65.64^{*}$ \\
Station 2 & & 1.00 & 47.95 \\
Station 3 & & & 1.00 \\
\hline
\end{tabular}

${ }^{*}$ Indicates significant similarity $(\mathrm{p}<0.50)$.

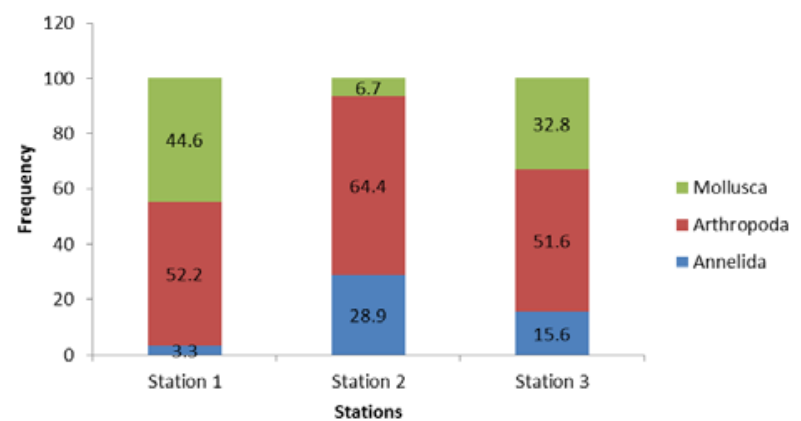

Fig. 2. Percentage contribution of macroinvertebrate groups in the study stations of River Idemili

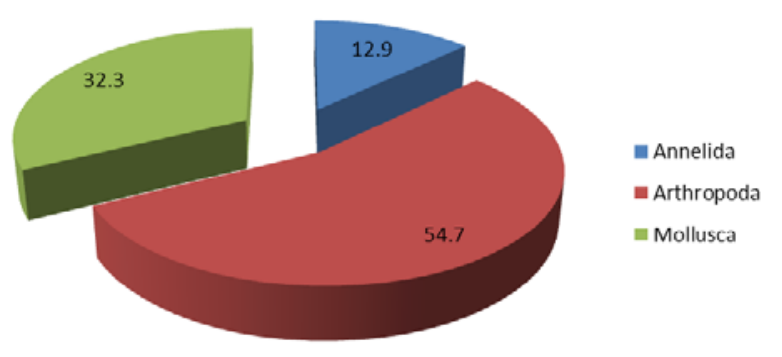

Fig. 3. Relative percentage composition of major macroinvertebrate phyla of River Idemili 


\section{Conclusions}

Conclusively, the results of this study showed that abattoir wastes distort water quality and affect the community structure, composition, distribution and abundance of macroinvertebrates inhabiting aquatic environments. Thus there was low abundance and diversity of macroinvertebrates in station 2. Stations 1 and 3 with stable microhabitat availability had high faunal abundance and diversity.

\section{References}

Aboheweyere PO (1990). Study of limnological parameters and potential fish yield in Kigera reservoir (extensive system) in Kainji, New Bussa, Nigeria. Journal of Aquatic Science 5:53-58.

Adeniji HA (1986). Some limnological precautions for fish farmers. Kainji Lake Research Institute Annual Report 1986:5456.

Agwa OK, Sito E, Ogubue CJ (2013). A spatial assessment of the microbiological and physico-chemical quality of a stream receiving raw abattoir waste. Middle-East Journal of Scientific Research 14(7):879886.

Ambili T, Reenamole GR (2016). Diversity and distribution of benthic macro invertebrates in Ayiroor River, Kerala, South India. International Journal ofScientific Research 5(3):1146-1149.

American Public Health Association (APHA). (1998). Standard methods for the examination of water and wastewater $\left(20^{\mathrm{t}} \mathrm{Ed}\right)$. American Public Health Association, APHA Washington DC, USA.

Anadu DI (1987). The contribution of water discharge to the distribution of macroinvertebrates in Dilimi System, a flashy stream in Jos-Plateau of Nigeria. Nigerian Journal of Applied Fisheries and Hydrobiology 2:5-9.

Arimoro FO, Ikomi RB, Osalor EC (2006). The impact of sawmill wood wastes on the water quality and fish communities of Benin, Niger Delta Area, Nigeria. World Journal ofZoology 11(2):94102.

Armitage PD, Cranston PS, Pinder LCV (1995). The Chironomidae: biology and ecology of non-biting midges. Chapman and Hall, London.

Ayoade AA, Olusegun AO (2012). Impacts of effluents on the limnology of a tropical river, Southwestern Nigeria. Journal of Applied Scientific and Environmental Management 16(2):201-207.

Bhosale PR, Chavan RJ, Graikwad AM (2012). Studies on distribution and diversity of chironormid larvae (Insecta: Diptera), with respect to water quality in Salim Ali Lake, Aurangabad, India. The Bioscan 7(2):233235.

Department for International Development (DFID) (1999). A simple methodology for water quality monitoring. Department for International Development, Wallingford.

Dondurff AJ, Shunway T (1998). Dissolved oxygen requirement for freshwater organisms. FAO Fishery Technical Paper 86:283-291.

Egborge ABM (1993). Biodiversity of aquatic fauna of Nigeria. Natural Resources Conservation Council, Abuja, Nigeria

Ekeh IB, Sikoki FD (2003). The state and seasonal variability of some physico-chemical parameters in the New Calabar River, Nigeria. Supplementa Ad Acta Hydrobiologica 5:45-60.

Emere MC, Nasiru CE (2008). Macroinvertebrates as indicators of the water quality of an urbanized stream, Kaduna Nigeria. Nature and Science 6(4):1-7.
Environmental Protection Agency (EPA) (2009). Safe drinking water standards. US Environmental Agency (EPA). Retrieved 13 October 2015 from http://www.epa.gov/OGWDW/mcl/html.

Ezekiel EN, Hart AI, Abowei JFN (2011). The distribution and seasonally of benthic macro-invertebrates in Sombreiro River, Niger Delta, Nigeria. Research Journal of Applied Science, Engineering and Technology 3(4):264271.

Galicka W,Lesiak T, RzezychaE (1992).Dynamics of phytoplankton in the Sulejow Reservoir (Central Poland) as related to nutrients and zooplankton pressure. Acta Hydrobiologica 34(4):303-314.

Ganf GG, Viner AB (1973). Ecological stability in a shallow equatorial lake (Lake George, Uganda). Proceedings of the Royal Society of London B: Biological Sciences 184(1076):321-346.

Gibbons WM, Funk HW (1982). Seasonal patterns in the zooplankton communities of a eutrophic lake on Eastern Washington prior to restoration. Journal of Freshwater Ecology 1(6):615-628.

Johnson PD (2005). Sustaining America's aquatic biodiversity. Freshwater snail biodiversity and conservation. Virginia Cooperative Extension, Virginia Tech, Blacksburg and Virginia State University, Petersburg.

Jordan WR, Gilpin ME, Aber JD (1990). Restoration ecology: a synthetic approach to ecological research. Cambridge University Press, Cambridge.

King RP (1998). Physico-chemical indices of the fisheries potential of a Nigerian rainforest pond. Journal of Aquatic Science 13:49-54.

Krebs CJ (1978). Ecology: the experimental analysis of distribution and abundance. Second Edition, Harper and Row Publisher,New York.

Magurran A (1988). Ecological diversity and its measurements. Groom Helm, London.

Odum EP (1971). Fundamentals of ecology (Third Ed). Saunders WB, London.

Ofojekwu PC, Umar DN, Onyeka JOA (1996). Pollution status of industrial wastes and their effects on macroinvertebrate distribution along Anglo-Jos water channel, Jos, Nigeria. Journal of Aquatic Science 11:1-6.

Ogbeibu AE, Egborge ABM (1995). Hydrobiological studies of water bodies in the Okomu Forest Reserve (Sanctuary) in Southern Nigeria (1). Distribution and diversity of the invertebrate fauna. Tropical Freshwater Biology 4:1-27.

Ogbeibu AE (2005). Biostatistics: a practical approach to research and data handling. Mindex Publishing Company Limited, Benin, Nigeria.

Pennak RW (1978). Freshwater invertebrates of the United States. Second Edition.John Wiley and Sons Inc, New York.

Pérez-Quintero JC (2011). Freshwater mollusc biodiversity and conservation in two stressed Mediterranean basins. LimnologicaEcology and Management of Inland Waters 41(3):201-212.

Rosenberg DM (1998). Freshwater benthic ecology and aquatic entomology. Soil and Water Conservation Society of Metro Halifax (SWCSMH). http//www.lakes.chebu eto.org//zoobenth/Benthes/ benthos intro.

Smart UN (2002). Environmental management and protection $\left(2^{\text {nd }} \mathrm{Ed}\right)$. Department of Urban and Regional Planning, University of Nigeria, Enugu Campus, Enugu, Nigeria pp 148-153.

Smith VH, Imam GD, NekolaJC (1999). Eutrophication: impacts of excess nutrient inputs on freshwater, marine and terrestrial ecosystems. 
486

Environmental Pollution 100(1):179-196.

Statzner B, Higler B (1986). Stream hydraulics as a major determinant of benthic invertebrate zonation patterns. Freshwater Biology 16(1):127139.

Thorp JH, Rogers DC (2011). Field guide to freshwater invertebrates of North America. Academic Press, USA.

Trevor D, Caston M, Zwelabo S (2010). An assessment of the effect of industrial and sewage effluent on aquatic invertebrates. A case study of a southern urban stream, Zimbabwe. Journal of Sustainable Development 3(2):210-212.

TubonimiJMI,Omubo A, Herbert OS (2010). Assessment of water quality along Amadi Creek in Port-Harcourt, Nigeria. Scientia Africana 9(1):150-162.
Victor R, Ogbeibu AE (1985). Macrobenthic invertebrates of a Nigerian stream flowing through farmland in Southern Nigeria. Environmental Pollution Series A, Ecological and Biological 39(4):337-349.

Waldichuk M (1974). Coastal marine pollution and fish. Ocean Management 2(1):1-60.

World Health Organization (WHO) (1993). International standard for drinking water quality. World Health Organization, Geneva.

World Health Organization (WHO) (2004). Guidelines for drinking water quality ( $\left.3^{\text {rd }} \mathrm{Ed}\right)$, Volume 1, Recommendations. World Health Organization, Geneva pp 210-220.

Zar TH (1984). Biostatistical analysis (2 ${ }^{\text {nd }}$ Ed). Prentice Hall, New Jersey, USA. 